\title{
The Effect of Bleaching on the Morphology of Enamel
}

\author{
Kavita \\ Student \\ Faculty of Dentistry, Universitas Sumatera Utara \\ Medan, Indonesia
}

\author{
Sumadhi Sastrodihardjo \\ Department of Dental Material \\ Faculty of Dentistry, Universitas Sumatera Utara \\ Medan, Indonesia
}

\begin{abstract}
Enamel of the teeth is the hardest tissue in the human body which protects them. The composition of enamel is $94-96 \%$ inorganic, $1 \%$ organic, and $4-5 \%$ water. Discoloration of the enamel which may be caused by chemicals, medicine or trauma has a psychological impact in person, characterized by lack of self-confidence. The bleaching material will produce free radicals and interact with the source of the discoloration causing compounds and break down the discoloration molecular bonds into simple compound forms resulting in elimination of discoloration and reaching the saturation point. If continue this process (over bleaching), it will damage the tooth structure. Bleaching materials give unwanted side effects on the enamel tissue, particularly changes in enamel morphology such as porosity, crater, depression, increased enamel depth, and missing asprimatic layers. Lack of attachment between hydroxyapatite crystals after exposure to bleaching materials can occur due to the enamel experiencing protein characterized by the formation of larger crystal gaps, altered crystalline shapes, and increased porosity. This article will also describe a mixture of sweet potatoes with a solution of hydrogen peroxide during the bleaching process in order to reduce free radical resulting in reduced risks on the morphology of enamel such as morphological surface irregularities, reduced groove, and no crater.
\end{abstract}

Keywords-bleaching, morphology, enamel tissue, protein, hydroxyapatite

\section{INTRODUCTION}

Dental discoloration, especially in the anterior teeth of adults, can cause aesthetic problems of teeth that have an impact on psychology, characterized by low self-confidence [1]. Tooth discoloration is known as tooth discoloration. Tooth discoloration can be caused by two factors, including extrinsic food and beverages containing chromatogenic and cigarettes; and intrinsic caused by trauma, drug use, and aging.

Everyone wants to get white teeth, because white teeth can make beautiful smile and enhance a sense of self-confidence [1]. Bleaching is one of the aesthetic applications in the field of dentistry that can restore discolored discoloration of natural teeth by chemical reactions with bleaching materials such as hydrogen peroxide and carbamide peroxide [4]. Most of the people choose bleaching treatment because the treatment is very simple, less expensive and get high patient satisfaction [3].
Enamel tooth contains $95 \%$ inorganic materials of hydroxyapatite crystals and less organic matter is proteins. The organic layer makes enamel into a semi permeable membrane. Molecular hydrogen peroxide is having low molecular weight can easily enter into the tooth structure and react chemically with tooth discoloration and tooth structure [5]. Teeth whitening occur because the bleaching material generates free radicals in the tooth structure to interact and decompose the source of the discoloration compound into simple molecules resulting in discoloration elimination. Although bleaching successfully produces white color tooth, it provides unwanted side effects on tooth tissue, especially enamel [4].

Bleaching materials can affect enamel tissue in a variety of aspects, including permeability, demineralization, morphology, and composition, and roughness, risk of dental caries, hardness, and flexural strength. This paper will discuss more deeply about the effect of bleaching materials on enamel morphology.

\section{LITERATURE REVIEW}

\section{A. Bleaching}

Materials that produce discoloration colors on tooth surfaces are organic compounds having a single or double chain bond, i.e. carbonyl and a phenyl ring known as chromophore [7]. During bleaching process, hydrogen peroxide contacts the chromophore and decomposes into $\mathrm{H} 2 \mathrm{O}$ and free oxygen. Free oxygen reaction is an unstable free radical $(-\mathrm{OH},-\mathrm{OOH}-$, and O2-) and will break the bond of the chromophore into smaller bonds and produce white to the teeth $[6,8]$.

When all chromophores have been broken down into less colored molecules (saturation points), then the teeth whitening process must be stopped. If the bleaching process continues (over bleaching), then decomposition of organic matter occurs, which can lead to complex oxidation with the result of carbon dioxide $(\mathrm{CO} 2)$ and water $(\mathrm{H} 2 \mathrm{O})$. With the over bleaching, the protein matrix on the enamel and dentine is oxidized, causing changes in enamel and dentin structure [9].

\section{B. Enamel}

Almost $96-98 \%$ by weight of inorganic mineral is found in matured enamel, and the remaining are water and organic materials [9].The enamel mineral consists of a calcium phosphate salt in the form of crystalline 
hexagonal hydroxyapatite (HA) with $\mathrm{Ca} 10(\mathrm{PO} 4) 6(\mathrm{OH}) 2$. Long enamel crystals in the c-axis area and bind to rod crystal or prism. The enamel rod or prism enamel is the basic unit of the enamel, which is parallel to each other and perpendicular to the dentino enamel junction (DEJ) on the tooth surface. The crystal around the rod is known as interprismatic or interrod. Among the enamel rod and enamel interrod there is a sheath rod which has a thin organic matrix that does not contain crystalline [9].

The organic matrix is present in the sheath rod and around the crystalline which makes the enamel into a semi permeable membrane, so that small molecules can enter freely into the enamel. Peroxide solution can enter freely into enamel and dentine, due to the low molecular weight of peroxide $(30 \mathrm{~g} / \mathrm{mol})$ so that it can whiten the entire surface of the tooth [9].

\section{Effect of bleaching against the network on enamel morphology}

The bleaching material may lead to changes in enamel morphology, such as changes in enamel texture and enamel crystals. Changes in the morphology of the enamel can be identified with the help of scanning electron microscopy (SEM), high resolution transmission electron microscopy (HR-TEM), and atomic Force Microscopy (AFM).

Changes in enamel morphological texture found in bleaching peroxide using SEM are erosion, porosity, enamel irregularity, aprismatic layer loss, groove and crater $[10,11,12]$.

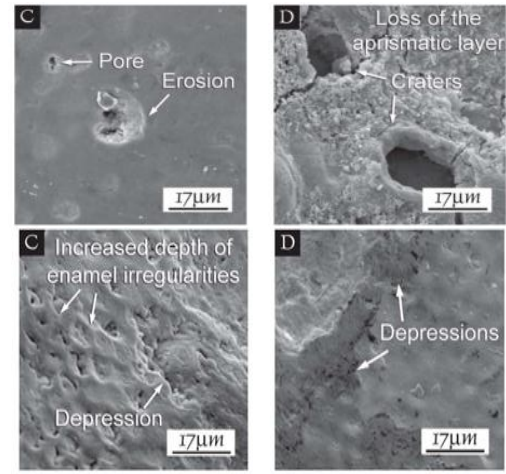

Figure 1. Results of photomicrograph on bleeding teeth with peroxide material [12].

The enamel of hydroxyapatite crystals is generally solid in the rod structure and interrod enamel. When, enamel exposed with bleaching material can make the crystal bond around the rod structure and interrod more loose so that the increase of space and porosity between the crystal (Figure 2) [13].

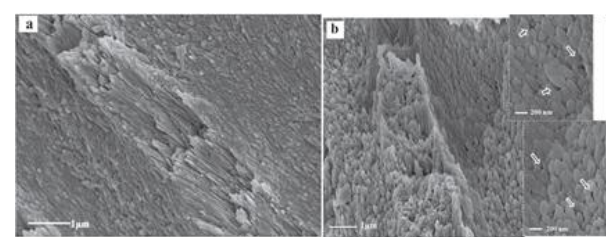

Figure 2. SEM results on enamel control hydroxy-apatite crystals (a) and bleaching (b) [13].
The enamel of crystals can also be checked using HR-TEM (high resolution transmission electron microscopy). Normal enamel of crystals that reside in c axis show a flat and elongated hexagonal crystal and there is a center of dark line in the center of crystal with unlimited white spots around it (Figure $3 a$ and b) [14].

The enamel of crystals after exposure to bleaching materials with $35 \%$ hydrogen peroxide were showed that crystal form to be irregular and some crystals grew in the direction of a axis. The crystal gap is slightly wider and the crystal growth becomes rather short. The dark lines are clearly visible in the middle of the crystal and with the white patches decreasing (Figure $3 \mathrm{c}$ and $3 d)$. Meanwhile, enamel of crystals bleached with 10$22 \%$ carbamide peroxide are found to be smaller and fragmented, some crystals perforate in the middle and crystal dissolution (Figure 3e and 3f) [14].

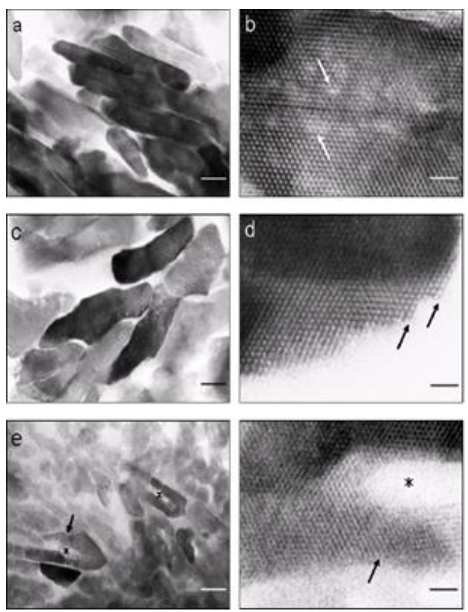

Figure 3. Results of hr-tem examination on enamel control (a, b) enamel bleaching with $35 \%$ hydrogen peroxide (c, d), and $10-22 \%$ hydrogen peroxide (e, f) [14].

Examination using AFM can give an overview of topographic results on enamel surface. Enamel surface exposed to bleaching materials of $10 \%$ carbamide peroxide makes enamel surface become more irregular like deep peaks and valleys. This happens because many layers of microporeus occur on enamel tissue. Microporeus may also increase when using higher carbamide peroxide gel concentrations (Figure 4) [15].
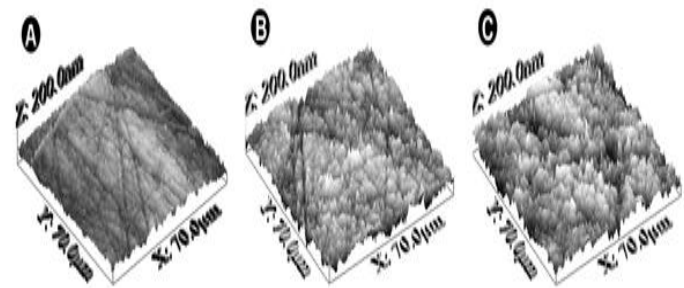

Figure 4. The enamel surface results using afm.15 (a) smooth (control), (b) irregular and groove shaped (10\% CP), (c) more irregular and more pore $(16 \% \mathrm{CP})$.

\section{DISCUSSION}

The bleaching procedure should not be excessive because the decomposition of the hydrogen peroxide material will interact with the organic components of 
the teeth (proteins and lipids) resulting in organic loss that can make the enamel surface rough. Generally, the enamel crystals are covered by proteins. Once the exposure time of the bleaching material can partially remove protein so that crystal surface is exposed [18].

Inorganic component are also of the dissolved enamel which means by penetrating the bleaching material to the intra and interprismatic areas of the enamel as to add a small gap in the prism sheath and between the crystals. Partial crystal growth was also found due to the hydroxyapatite deposits on the surface of the crystals slightly $[17,18]$.

The changes of enamel structure occurs because of the hydrogen peroxide material that is in contact with the dental chromophore where decomposes into an unstable free radical oxygen reaction to make the chromophore bond less and the teeth become white. However, these free radicals are not good for teeth, so a mixture of sweet potato peroxide materials is developed to reduce the free radicals that are in contact with teeth.

Sweet potato (Ipomoea batatas L) is one of the plants containing antioxidant molecules with high enzyme content such as catalase (CAT). The catalase enzyme from the sweet potato is added to the hydrogen peroxide material as to reduce high energy activation and increase the rate of free radical release. Activation of hydrogen peroxide energy is $75 \mathrm{~kJ} / \mathrm{mol}$. When catalase is added to hydrogen peroxide it forms a catalase-hydrogen peroxide complex and decreases the activation of energy to $21 \mathrm{~kJ} / \mathrm{mol}$. Large quantities of free radicals from hydrogen peroxide can be released with shorter periods of time. By reduced bleaching time in contact with the teeth resulting in reduced grooves or micropores on the enamel surface [17].

Generally, enamel surfaces that have been bleached make a rough enamel surface, missing asprimatic, cracked and formed crater. Whereas, bleaching material added with sweet potato can make the enamel morphology irregularities diminish and no visible cracks (Figure 5) [17].

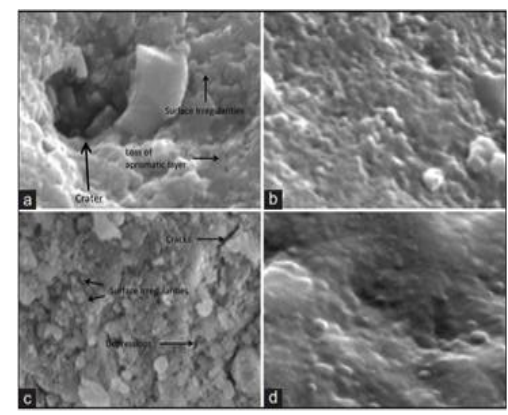

Figure 5. SEM examination results on the enamel surface [17]. A. Missing layers aprismatik, krakter, and irregular (35\% $\mathrm{H} 2 \mathrm{O} 2$ ). B. Irregular surfaces are reduced, no crates and cracks $(35 \% \mathrm{H} 2 \mathrm{O} 2+$ sweet potato) c. Missing layers of asprimatic, irregular surfaces, cracks, and depression (10\% $\mathrm{H} 2 \mathrm{O} 2)$ d. Reduced irregular surface, no crates and cracks $(10 \% \mathrm{H} 2 \mathrm{O} 2+$ sweet potato)

As a conclusion, bleaching materials can cause structural changes in enamel, including dissolved organic and inorganic components, as well as changes in enamel morphology in the form of porosity, crater, depression, increased enamel depth, loss of asprimatic layers, and uneven surface of enamel such as peaks and valleys. Minimizing free radicals by addition of sweet potato extracts into the hydrogen peroxide material can decrease the effect on enamel morphology.

\section{REFERENCES}

[1] M. Syafriadi M, T.C. Noh TC, "Pengukuran kadar kalsium saliva terlarut pada gigi yang dilakukan eksternal bleaching dan dipapar dengan Streptococcus mutans," PDGI J., vol. 63(2), pp. 63-65, 2014.

[2] M.Q. Alqahtano, "Tooth-bleaching procedures and their controversial effects: A literature review," Saudi Dent. J., vol. 26, pp. 33-46, 2014.

[3] Asmawati, M. Aulia, "Pemanfaatan buah strawberry sebagai pemutih gigi," Makassar Dent. J., vol. 5(2), pp. 40-43, 2016.

[4] S. Jafkar, "Pengaruh agen aktif bleaching terhadap jaringan kerasa dan lunak mulut serta bahan restorasi kedokteran gigi," Cakradonya Dent. J., vol. 2(1), pp. 62-68, 2009.

[5] D. Horning, G.M. Gomes, B.F. Biitencourt, L.M. Ruizz, A Reis, O.M.M. Gomes, "Evaluation of enamel permeability exposed to bleaching agents," Braz. J. Oral Sci. vol. 12(2), pp. 114-118, 2013.

[6] S.R. Kwon, P. Wertz, "Review of the mechanism of tooth whitening,” JERD., vol. 27(5), pp. 240-257, 2015.

[7] S.B. Joshi, "An overview of vital teeth bleaching," J. Interdiscip. Dentistry, vol. 6, pp. 3-13, 2016.

[8] Innedce (2017, January 20) A review of tooth whitening services. Available: <https://www.ultradent.com/en-us/DentalProducts-Supplies/Tooth-Whi tening/take-home whitening /Opale scence-PF-Carbamide-Peroxide-with-Potassium-Nitrateand-Fluoride/ Docum ents/Whitening-CE_1506cei_Nagelberg whitening_rev3.pdf>.

[9] $\bar{X}$. Wang, Structural aspects of bleaching and fluoride application on dental enamel, Dissertation, University of Hamburg, 2008, pp. 3-23.

[10] H.M. Elfallah, M.A. Swain, "A review of the effect of vital teeth bleaching on the mechanical properties of tooth enamel," N. Z Dent. J., vol. 109(3), pp. 87-96, 2013.

[11] R. Paulo, D. Barral, M. Cajazeria, "A comparative study of the effects of two carbamide peroxide bleaching agents on the structure of enamel,” Rev. Gauch. Odontol., vol. 64(3), pp. 293 298, 2016.

[12] C.B. Miranda, C. Pagani, A.R. Benett, F.S. Matuda, "Evaluation of the bleached human enamel by scanning electron microscopy,” J. Appl. Oral Sci., vol. 13(2), pp. 204-211, 2005.

[13] H.M. Elfallah, L.E. Bertassoni, N. Charadram, C. Rathsam, M.V. Swain, "Effect of tooth bleaching agents on protein content and mechanical properties of dental enamel," J. Actio., vol. 20, pp. 120-128, 2015 .

[14] M. Ogiwara, Y. Miake, T. Yanagisawa, "Changes in dental enamel crystals by bleaching," J. Hard Tissue Biology, vol. 17(1), pp. 11-16, 2008.

[15] D.G. Soares, A.P.D. Riberio, N.T. Sacono, A. Dourado,J. Hrbling, C.A.S Cocta, "Mineral loss and morphological changes in dental enamel induced by a $16 \%$ carbamide peroxide bleaching gel," Braz. Dent. J., vol. 24(5), pp. 517-521, 2013.

[16] A. Saleem, A. Anwer, M. Kallem, et al., "A comparative analysis of bleached and sound enamel structure through scanning electron microscopy and atomic force microscopy," Pak. Armed Forces Med. J., vol. 65(3), pp. 371-373, 2015.

[17] S. Gopinath, V. James, S. Vidhya, K. Karthikeyan, S. Kavitha, S. Mahalaxmi, "Efect of bleaching with two different concentrations of hydrogen peroxide containing sweet potato extract as an additive on human enamel: An in vitro spectrophotometric and scanning electrone microscopy analysis," J. Conserv. Dent., vol. 16, pp. 45-49, 2013.

[18] M. Nair, R. Nesamani, K. Sanjeev, M. Sekar, S. Renganathan, "Effects of single and two step application of antioxidant incorporated bleaching agents on bond strength of resin composite and surface changes in enamel," Biol. Med., vol. 8 , pp. 1-7, 2016. 